\title{
Evaluation of progression of hepatic fibrosis in a group of patients with non-alcoholic fatty liver disease accompanied for $\mathbf{1 0}$ years
}

\author{
Paula Cenira Senger de CASTR0¹, Helen Caroline Perussolo ALBERTON¹, Maria Lucia Alves PEDR0SO², \\ Daphne Benatti Gonçalves MORSOLETTO ${ }^{1}$, Alcindo PISSAIA JUNIOR ${ }^{1}$ and \\ Cláudia Alexandra Pontes IVANTES ${ }^{1}$
}

Received 18/1/2019

Accepted 18/6/2019

\begin{abstract}
Background - Non-alcoholic fatty liver disease has been progressively diagnosed in the general population as a consequence of the increased prevalence of obesity and type 2 diabetes mellitus, its main risk factors. It is characterized by accumulation of fat in the hepatocytes associated with lobular inflammation and balonization, which can lead to cirrhosis and hepatocarcinoma. Thus, a characterization and follow-up of a progression of the fibrosis level of these patients becomes important, being that the transient hepatic elastography is a reliable method for this evaluation with a measure of the kapa index. Objective - To evaluate the progression of hepatic fibrosis through elastography in patients with non-alcoholic fatty liver disease. Methods - Patients who had previously performed hepatic biopsy and noninvasive scores for non-alcoholic steatohepatitis (NASH) and fibrosis were included in the study. These same subjects were then submitted to current clinical evaluation, laboratory and liver elastography tests, defining the level of liver fibrosis, about 10 years after the first evaluation. Results - Data were analyzed for 66 patients previously submitted to liver biopsy. Of these, 16 were not found, four could not participate because they were debilitated due to hepatic cirrhosis, two had died from an automobile accident and five from complications of cirrhosis of the liver. Therefore, of the 50 patients with a known history, $9(18 \%)$ had died of cirrhosis or were unable to attend the examination because of their liver disease. The remaining population was predominantly female $(61.5 \%)$, mean age of 63 years, being overweight, dyslipidemia (76.9\%), disorders of the glycemic profile ( $76.9 \%)$, and metabolic syndrome $(82.1 \%)$. Of the 39 cases evaluated, $35 \%$ had the same degree of fibrosis at the initial evaluation (biopsy) and at the current evaluation (elastography), $33 \%$ had an increase in the degree of fibrosis and another 30\% had a decrease in the degree of fibrosis. Twenty-eight patients had NASH at baseline. Regarding these patients, it was observed in the current evaluation, that $25 \%$ remained stable in the degree of fibrosis, $39 \%$ progressed, and $35 \%$ regressed. Conclusion - Despite some limitations of our study, such as the small number of patients, and the use of two different methods of evaluation (biopsy and elastography), the data obtained allow us to conclude that of the 39 evaluated cases, $33 \%$ (13) presented progression of fibrosis and the total group of 50 patients, $42 \%$ had cirrhosis or died due to liver disease. The presence of NASH on hepatic biopsy did not prove to be, in our study, a predictive of the evolution of hepatic fibrosis in the patients.
\end{abstract}

HEADINGS - Non-alcoholic fatty liver disease. Elasticity imaging techniques. Liver cirrhosis. Fatty liver.

\section{INTRODUCTION}

Nonalcoholic fatty liver disease (NAFLD) is becoming the most common liver disease worldwide as a consequence of the increased prevalence of obesity and diabetes mellitus, considered to be its main risk factors ${ }^{(1)}$. NAFLD is defined as a condition in which there is excessive deposition of liver fat (hepatic steatosis) in the form of triglycerides in a proportion greater than $5 \%{ }^{(2)}$.

In clinical practice, the initial diagnosis of NAFLD is typically established through the clinical profile (patient with metabolic syndrome) associated with laboratory tests (possibly increased transaminases and gamma glutamyl transferase) and radiological examinations (liver steatosis on ultrasound), in the absence of other known causes of steatosis (alcohol, hepatitis C, drugs) ${ }^{(3)}$.
Clinically, NAFLD may present from a simple hepatic steatosis, not accompanied by significant hepatic inflammation, to a nonalcoholic steatohepatitis (NASH), which has the potential to develop hepatic cirrhosis and its complications, such as hepatocarcinoma and terminal hepatic impairment ${ }^{(4)}$. The evaluation of laboratory and imaging data in a patient with NAFLD may only suggest the presence of NASH, but the confirmation of this diagnosis necessarily depends on the performance of a liver biopsy. The histological criteria of NASH have been well established and recently reviewed, including: evidence of macrovesicular steatosis, mixed inflammatory infiltrate, Mallory corpuscles, hepatocellular ballooning and necrosis of hepatocytes associated with perisinusoidal hepatic fibrosis in varying degrees. The intensity of these findings, especially hepatic fibrosis, is proportional to the severity of the $\mathrm{NASH}^{(4,5)}$. 
The biopsy allows direct assessment of liver tissue and is now considered as the gold standard method for the diagnosis, staging and graduation of various chronic liver diseases, including NAFLD. However, it is a method that is not easily available to the population in general, has a high cost and presents risks inherent to the procedure ${ }^{(6)}$. Over the last few years, several non-invasive methods for diagnosing liver fibrosis have been developed and validated. Imaging methods such as elastography have been successfully used to assess hepatic fibrosis in NAFLD by measuring elasticity of the liver based on the emission of elastic waves ${ }^{(7)}$. The values of these measurements can vary from 3.5 to $75 \mathrm{kapa}$, depending on the degree of hepatic fibrosis, and their correlation with stages of fibrosis according to METAVIR classification ${ }^{(8)}$. The aim of this study is to evaluate the progression of hepatic fibrosis through elastography in patients with NAFLD; and whether the presence of NASH on hepatic biopsy would be a predictor of liver fibrosis evolution.

\section{METHODS}

Patients who underwent liver biopsy and noninvasive scores for assessing steatohepatitis and liver fibrosis in previously study were included ${ }^{(9)}$. Patients underwent clinical, laboratory, and elastography examination, defining the current level of hepatic fibrosis, about 10 years after the first evaluation.

The results of the liver biopsies performed in the previous study were evaluated. The criteria for diagnosis, graduation and staging of NAFLD followed the classification proposed by Kleiner, in which the histological findings of hepatic steatosis, hepatocellular ballooning and lobular inflammation are analyzed, allowing the calculaton of an index, ranging from 0 to 8 points ${ }^{(5)}$. The sum of these points corresponds to an index defined by Kleiner: $\leq 2$ diagnosis of steatohepatitis is unlikely, and if $\geq 5$ a diagnosis of steatohepatitis should be considered, taking into account that the numeric value should not be considered a replacement of the pathologist's diagnosis. Besides these findings be related to the graduation of the disease, the observation of the intensity of the hepatic fibrosis allowed staging of NAFLD, which, in this model, was based in the following classification: absent $=0$, perisinusoidal or periportal $=1$, perisinusoidal and periportal $=2$, broad fibrous septa $=3$ and cirrhosis $=4$.

Patients were evaluated for clinical, laboratory and transient elastography, and for comparative measurements with non-invasive and hepatic biopsy scores, was used the values of the kapa and controlled attenuation parameter (CAP) indices. The best quality examination was considered after obtaining 10 valid measures with IQR (interquartile range) $\leq 20 \%$. The CAP measurements were classified in $\mathrm{S} 0$ (steatosis less than or equal to $10 \%$ ) when the CAP value was less than $213 \mathrm{~dB} / \mathrm{m}, \mathrm{S} 1$ (steatosis between $11 \%$ and $33 \%$ ) when the CAP value was 214 to $254 \mathrm{~dB} / \mathrm{m}, \mathrm{S} 2$ (steatosis between $34 \%$ and $66 \%$ ) when the CAP value was 255 to $280 \mathrm{~dB} / \mathrm{m}$, and $\mathrm{S} 3$ (steatosis greater than or equal to $67 \%$ ) when the CAP value was greater than $281 \mathrm{~dB} / \mathrm{m}$. The kapa measurements were classified as F0, when the kapa value was less then 6.1, F1 when the kapa value was between 6.1 and 7.1, F2 when the kapa value was between 7.1 and 8.9, F3 when the kapa value was between 8.9 and 11.8 , and F4 when the kapa value was greater than $11.8^{(10,11)}$.

The results obtained in the study were described by averages, medians, minimum values, maximum values and standard deviations (quantitative variables) or by frequencies and percentages (categorical variables). For the comparison of the two evaluations (previous and current), in relation to quantitative variables, the Student's $t$-test for paired samples (BMI and cholesterol) or Kruskal-Wallis non-parametric test (glucose) was used. The variables normality condition was evaluated by the KolmogorovSmirnov test. Values of $P<0.05$ indicated statistical significance.

\section{RESULTS}

Data were analyzed for 66 patients previously submitted to liver biopsy. Of these, sixteen were not found, four could not participate because they were debilitated due to hepatic cirrhosis, two had died from a car accident and five from complications of cirrhosis. Therefore, of the 50 patients with known evolution, nine (18\%) had died of cirrhosis or were unable to attend the examination because of their liver disease (TABLE 1). Thirty-nine patients signed the informed consent form and agreed to participate in the study, $61.5 \%$ female, with a mean age of 63.9, body mass index (BMI) of $29 \mathrm{~kg} /$ $\mathrm{m}^{2}$ and abdominal circumference of $103.4 \mathrm{~cm}$. The other clinical data are shown in TABLE 2.

TABLE 1 . Outcome of patients.

\begin{tabular}{lcc}
\hline & $\mathrm{N}$ & $\%$ \\
\hline Death by accident & 2 & $4 \%$ \\
Cirrhosis as the cause of death & 5 & $10 \%$ \\
Debilitated due to hepatic cirrhosis & 4 & $8 \%$ \\
Included in the analyzes & 39 & $78 \%$ \\
Total & 50 & $100 \%$ \\
\hline
\end{tabular}

TABLE 2. Clinical aspects of patients, in percentage (\%).

\begin{tabular}{lll}
\hline & $\mathbf{n}$ & $\%$ \\
\hline Gender & & \\
$\quad$ Female & 24 & 61.5 \\
$\quad$ Male & 15 & 38.5 \\
DM / glucose intolerance & 30 & 76.9 \\
SAH & 26 & 66.7 \\
Dyslipidemia & 30 & 76.9 \\
MS & 32 & 82.1 \\
Obesity / overweight & 34 & 87.1 \\
\hline
\end{tabular}

DM: diabetes mellitus; SAH: systemic arterial hypertension; MS: metabolic syndrome. Percentage calculated in relation to the total number of patients $(n=39)$.

In order to compare the clinical data, an analysis was performed including the patients with information available in the two evaluations (TABLE 3). A significant difference was observed in the comparison of the BMI and also the cholesterol dosage, showing a decrease of the same in the current evaluation. While the serum glucose increased, also with significant difference.

The data by transient elastography examination allowed us to obtain adequate quality results with an IQR of $12.6 \%$ and an average of only 1.55 invalid measurements. The mean value of kapa was 12.0 (F4 of the METAVIR classification) and CAP of 293.9 $\mathrm{dB} / \mathrm{m}$, corresponding to steatosis $\mathrm{S} 3$.

When patients with NAFLD underwent the first evaluation of hepatic fibrosis, five (12.8\%) already presented cirrhosis and six $(15.38 \%)$, advanced fibrosis ( $\mathrm{F} 3$ or F4). In the second evaluation of fibrosis, $12(30.8 \%)$ were cirrhotic and $13(33.34 \%)$ had advanced fibrosis. In the evaluation of fibrosis progression, we observed that 
TABLE 3. Comparison of the clinical data obtained in the initial and current evaluation.

\begin{tabular}{lccccc}
\hline & n & Average & Medium & $\begin{array}{l}\text { Standard } \\
\text { deviation }\end{array}$ & $P$ value* \\
\hline $\begin{array}{l}\text { BMI initial } \\
\left(\mathrm{kg} / \mathrm{m}^{2}\right)\end{array}$ & 30 & 31.3 & 29.9 & 5.3 & \\
$\begin{array}{l}\mathrm{BMI} \text { current } \\
\left(\mathrm{kg} / \mathrm{m}^{2}\right)\end{array}$ & 30 & 29.0 & 28.0 & 4.6 & 0.001 \\
$\begin{array}{l}\text { WC initial }(\mathrm{cm}) \\
\text { WC current }\end{array}$ & 27 & 104.4 & 104 & 11.5 & \\
$\begin{array}{l}\text { (cm) } \\
\text { Glucose initial } \\
(\mathrm{mg} / \mathrm{dL})\end{array}$ & 29 & 143.8 & 115 & 63.2 & \\
$\begin{array}{l}\text { Glucose current } \\
(\mathrm{mg} / \mathrm{dL})\end{array}$ & 29 & 150.2 & 131 & 64.5 & 0.001 \\
$\begin{array}{l}\text { Cholesterol } \\
\text { initial }(\mathrm{mg} / \mathrm{dL})\end{array}$ & 26 & 184.3 & 181 & 36.7 & \\
$\begin{array}{l}\text { Cholesterol } \\
\text { current }(\mathrm{mg} / \mathrm{dL})\end{array}$ & 26 & 159.3 & 166 & 34.5 & 0.001 \\
\hline
\end{tabular}

BMI: body mass index; WC: waist circumference.

$14(35.89 \%)$ remained stable, $13(33.34 \%)$ presented fibrosis progression and $12(30.76 \%)$ had a fibrosis grade regression. Among the 14 stable patients, five $(35.71 \%)$ were already cirrhotic at the first evaluation. Regarding the presence of advanced fibrosis, six $(15.38 \%)$ of the individuals had advanced fibrosis in the period evaluated (TABLE 4).

TABLE 4. Combined liver fibrosis results in both evaluations.

\begin{tabular}{|c|c|c|c|c|c|c|}
\hline \multirow{2}{*}{$\begin{array}{l}\text { Biopsy (initial } \\
\text { evaluation of } \\
\text { fibrosis) }\end{array}$} & \multicolumn{5}{|c|}{$\begin{array}{l}\text { Elastography } \\
\text { (current evaluation of fibrosis) }\end{array}$} & \multirow[t]{2}{*}{ Total } \\
\hline & 0 & 1 & 2 & 3 & 4 & \\
\hline \multirow[t]{2}{*}{0} & 7 & & 1 & & 1 & 9 \\
\hline & $17.9 \%$ & & $2.6 \%$ & & $2.6 \%$ & \\
\hline \multirow[t]{2}{*}{1} & 8 & 2 & 4 & & 2 & 16 \\
\hline & $20.5 \%$ & $5.1 \%$ & $10.3 \%$ & & $5.1 \%$ & \\
\hline \multirow[t]{2}{*}{2} & 4 & & & 1 & 3 & 8 \\
\hline & $10.3 \%$ & & & $2.6 \%$ & $7.7 \%$ & \\
\hline \multirow[t]{2}{*}{3} & & & & & 1 & 1 \\
\hline & & & & & $2.6 \%$ & \\
\hline \multirow[t]{2}{*}{4} & & & & & 5 & 5 \\
\hline & & & & & $12.8 \%$ & \\
\hline Total & 19 & 2 & 5 & 1 & 12 & 39 \\
\hline
\end{tabular}

Table obteined from the 39 cases evaluated: 14 (35.9\%) had the same degree of fibrosis in the initial evaluation (biopsy) and in the current evaluation (elastography) (in blue). 13 (33.3\%) had an increase in the degree of fibrosis (in green); 12 (30.8\%) had a decrease in the degree of fibrosis (in light red).

Twenty-eight $(71.8 \%)$ patients presented NASH at the initial evaluation, according to the Kleiner's score. Regarding these patients, seven $(25 \%)$ remained stable in the degree of fibrosis, 11 $(39.3 \%)$ progressed, and $10(35.7 \%)$ regressed. In addition, of the twenty-eight patients previously with NASH, $10(35.7 \%)$ presented advanced fibrosis in the current evaluation. In the analysis, it was concluded that the presence of NASH was not able to predict the progression of fibrosis $(P=0.134)$.
Among the eight patients who presented progression of fibrosis to clinically significant values, six $(75 \%)$ had the diagnosis of NASH into hepatic biopsy, which occurred in $22(78.6 \%)$ of those who did not progress or even regressed $(P=0.427)$.

\section{DISCUSSION}

NAFLD is a growing public health problem due to its prevalence, possibility of progression to cirrhosis and hepatocarcinoma, and increased of cardiovascular risk. NAFLD is a clinical and pathological entity that ranges from the accumulation of liver fat (simple steatosis) to NASH. The risk of disease progression is directly related to the presence of NASH in the histological evaluation and the presence of other comorbidities such as type 2 diabetes mellitus, making it essential to identify these patients.

As described in studies, like Gallego-Durán et al. ${ }^{(12)}$ during the management of NAFLD, it is necessary to: a) detection of NASH, which could help to exclude patients who are not at risk of disease progression; b) Detection of significant fibrosis to select patients with worse prognosis and survival. And in fact, the strongest predictor of fibrosis progression in NAFLD is the presence of steatohepatitis.

NAFLD is often associated with cardiovascular disease risk factors: obesity, type 2 diabetes, and dyslipidemia. Obesity is established as a predictor of hepatic steatosis, but it may also exist in the absence of obesity. A recent analysis of studies involving more than 8.5 million people from 22 countries showed that over $80 \%$ of patients with non-alcoholic NAFLD are overweight or obese, $72 \%$ have dyslipidemia and $44 \%$ have been diagnosed with type 2 diabetes mellitus. This information supports the concept that the NAFLD is the hepatic correlation of the metabolic syndrome ${ }^{(13)}$. Similar to that described in our study, $87 \%$ of the patients were overweight or obese, and $76.9 \%$ has dyslipidemia. The laboratory findings were also similar to other previously performed studies such as Abrams et al. ${ }^{(14)}$, with a high prevalence of alterations of the glycemic metabolism, found in about $80 \%$ of the patients.

The different clinical parameters analyzed in this population, such as gender, BMI, waist circumference, glucose intolerance or diabetes and metabolic syndrome, did not allow to differentiate the presence or absence of fibrosis in the evaluated patients. These parameters were found in a similar proportion in all groups, as described by other authors ${ }^{(15)}$.

Nonalcoholic steatohepatitis is a dynamic condition that can regress to isolated steatosis at a constant level of activity, or causing progressive fibrosis that can progress to cirrhosis. Natural history studies indicate that the severity of liver fibrosis is the only histological measure that independently predicts the risk of liver related disease, liver transplantation and death. Sequential analyzes of liver biopsies in cohort studies indicate that hepatic fibrosis progresses at a rate of approximately one stage per decade; suggesting that patients with grade 2 fibrosis will progress to cirrhosis within 20 years. However, rates of progression (and regression) of fibrosis vary considerably from individual to individual. In some cases, for example, fibrosis rapidly decreases with the improvement of NASH, while in others, fibrosis persists or worsens even with resolution of $\mathrm{NASH}^{(13)}$.

A prospective four-year study has been conducted by Suzuki et al., in which the disease progression in NAFLD patients was evaluated using Elastography. Ninety-seven NAFLD patients (demonstrated by liver biopsy) had their liver stiffness measure- 
ments obtained at the beginning of the study; of the 97 patients, 36 patients were available for reevaluation after four years, in which their stage of fibrosis was compared with that from their initial assessment. A total of nine (25\%) patients had fibrosis progression, 17 $(47.2 \%)$ had static disease and $10(27.8 \%)$ had fibrosis remission ${ }^{(16)}$.

Argo et al. compiled longitudinal histological data to characterize the natural history of fibrosis progression in NASH patients and reported that according to follow-up biopsies, $37.6 \%$ patients progressed to a higher fibrosis stage, $41.6 \%$ exhibited no change and $20.8 \%$ exhibited improvement in fibrosis ${ }^{(17)}$. Our study showed similar results to those of their studies, although we followed fibrotic changes using transient elastography.

Wong et al. evaluated the discordance between fibrosis stages as per transient elastography and those as per histology and concluded that unsatisfactory liver biopsy specimens, and not transient elastography, account for most cases of discordance. The major advantages of liver elastography over liver biopsy are that it is painless, rapid and has no risk of complications, because of which it is very easily accepted by patients ${ }^{(18)}$.

Considering that in our study, of the 39 patients evaluated, five had cirrhosis, and in the current evaluation, seven more were diagnosed with cirrhosis (totaling twelve patients), it was concluded that although patients are being followed up in hepatology services, did not evolve better than described in the literature as natural. That is, the intervention in the natural history of the disease is not occurring effectively. In addition, in our study, the results did not correspond to the evolution of 1 degree of fibrosis every 10 years ${ }^{(19)}$.

In conclusion, of the 39 evaluated cases, 33\% (13) presented progression of fibrosis, and of the total group of 50 patients, $42 \%$ presented cirrhosis or died due to liver disease. Our study presents some limitations, such as the small number of patients, and the use of two different methods for evaluation (biopsy and elastography). The presence of NASH on hepatic biopsy did not prove to be, in our study, a predictive of the evolution of hepatic fibrosis in the patients.

\section{Authors' contribution}

Castro PCS: data collection, survey execution and text writing. Alberton HCP: data collection. Pedroso MLA: data collection and text revision. Morsoletto DBG: data collection. Pissaia Junior A: data collection. Ivantes CAP: text revision and research supervision.

\section{Orcid}

Paula Cenira Senger de Castro. Orcid: 0000-0002-8609-0486.

Helen Caroline Perussolo Alberton. Orcid: 0000-0002-2088-3432

Maria Lucia Alves Pedroso. Orcid: 0000-0002-1252-3402

Daphne Benatti Gonçalves Morsoletto. Orcid: 0000-00031060-7431

Alcindo Pissaia Junior. Orcid: 0000-0001-9573-9438

Cláudia Alexandra Pontes Ivantes. Orcid: 0000-0001-5422$557 \mathrm{X}$.

Castro PCS, Alberton HCP, Pedroso MLA, Morsoletto DBG, Pissaia Junior A, Ivantes CAP. Avaliação da progressão da fibrose hepática em um grupo de pacientes com doença hepática gordurosa não alcoólica acompanhados por 10 anos. Arq Gastroenterol. 2019;56(3):256-60.

RESUMO - Contexto - A doença hepática gordurosa não alcoólica vem sendo diagnosticada com frequência progressivamente maior na população geral, como consequência do aumento da prevalência da obesidade e do diabetes mellitus tipo 2, considerados seus principais fatores de risco. Caracteriza-se por acúmulo de gordura nos hepatócitos associada à inflamação lobular e balonização, podendo levar à cirrose e hepatocarcinoma. Desta forma, torna-se importante a caracterização e acompanhamento do nível de fibrose hepática destes pacientes, sendo que a elastografia hepática transitória, tem se mostrado um método confiável para esta avaliação com a medida do índice kapa. Objetivo - Avaliar a progressão da fibrose hepática através de elastografia em pacientes com doença hepática gordurosa não alcoólica. Métodos - Foram incluídos no estudo pacientes que haviam realizado anteriormente biópsia hepática e cálculo de escores não invasivos para avaliação de esteato-hepatite não alcoólica (EHNA) e fibrose. Estes mesmos indivíduos foram então submetidos à avaliação clínica, laboratorial e exame de elastografia hepática atuais, definindo o nível de fibrose hepática, cerca de 10 anos após a primeira avaliação. Resultados - Foram analisados dados relativos a 66 pacientes previamente submetidos a biópsia hepática. Destes, 16 não foram localizados, quatro não puderam participar por estarem incapacitados em função de cirrose hepática, dois haviam falecido por acidente automobilístico e cinco, por complicações de cirrose hepática. Portanto, do grupo de 50 pacientes com evolução conhecida, nove ( $18 \%$ ) haviam falecido por cirrose ou estavam incapacitados de comparecer ao exame em função de sua doença hepática. A população restante era predominantemente do sexo feminino (61,5\%), com idade média de 63 anos, apresentando sobrepeso, dislipidemia $(76,9 \%)$, distúrbios do metabolismo glicêmico $(76,9 \%)$ e síndrome metabólica (82,1\%). Dos 39 casos avaliados, 35\% tiveram o mesmo grau de fibrose na avaliação inicial (biópsia) e na avaliação atual (elastografia), 33\% tiveram aumento no grau de fibrose e outros 30\% tiveram diminuição no grau de fibrose. Vinte e oito pacientes apresentavam EHNA na avaliação inicial. Em relação a esses pacientes observou-se na avaliação atual que, $25 \%$ mantiveram-se estáveis no grau de fibrose, $39 \%$ progrediram e, $35 \%$ regrediram. Conclusão - Apesar de algumas limitações do nosso estudo, como o pequeno número de pacientes e o uso de dois métodos diferentes de avaliação (biópsia e elastografia), os dados obtidos nos permitem concluir que dos 39 casos avaliados, 33\% apresentaram progressão da fibrose e do grupo total de 50 pacientes, $42 \%$ apresentam cirrose ou faleceram em decorrência de doença hepática. A presença de EHNA à biópsia hepática não se mostrou um dado capaz, no nosso estudo, de predizer a evolução da fibrose hepática nos pacientes.

DESCRITORES - Hepatopatia gordurosa não alcoólica. Técnicas de imagem por elasticidade. Cirrose hepática. Fígado gorduroso. 


\section{REFERENCES}

1. Wree A, Kahraman A, Gerken G, Canbay A. Obesity affects the liver - the link between adipocytes and hepatocytes. Digestion. 2011;83:124-33.

2. Adams LA, Lymp JF, St Sauver J, Sanderson SO, Lindor KD, Feldstein A, et al. The natural history of nonalcoholic fatty liver disease: a population-based cohort study. Gastroenterology. 2005;129:113-21.

3. Mikoselavic I, Orlic L, Franjic N, Hauser G, Stimac D, Milic S. Transient elastography $($ FibroScan () with controlled attenuation parameter in the assessment of liver steatosis and fibrosis in patients with nonalcoholic fatty liver disease - Where do we stand?. World Journal of Gastroenterology. 2016;22:7236-51.

4. Brunt EM. Pathology of nonalcoholic fatty liver disease. Nature Reviews. Nat Rev Gastroenterol Hepatol. 2010;7:195-203.

5. Kleiner DE, Brunt EM, Van Natta M, Behling C, Contos MJ, Cummings OW, et al. Nonalcoholic steatohepatitis clinical research network. Design and validation of a histological scoring system for nonalcoholic fatty liver disease. Hepatology (Baltimore, Md). 2005;41:1313-2.

6. Rockey DC, Caldwell SH, Goodman ZD, Nelson RC, Smith AD. Liver biopsy. Hepatology. 2009;49:1017-44.

7. Clark PJ, Patel K. Noninvasive tools to assess liver disease. Current Opinion in Gastroenterology. 2011;27:210-6.

8. Wong VW, Vergniol J, Wong GL, Foucher J, Chan HL, Le Bail B, et al. Diagnosis of fibrosis and cirrhosis using liver stiffness measurement in nonalcoholic fatty liver disease. Hepatology. 2010;51:454-62.

9. Nones RB, Ivantes CP, Pedroso MLA. Can FIB4 and NAFLD fibrosis scores help endocrinologists refer patients with non-alcoholic fat liver disease to a hepatologist?. Arch Endocrinol Metab. 2017;61:276-281.
10. Sasso M, Tengher-Barna I, Ziol M, Miette V, Fournier C, Sandrin L, et al. Novel controlled atenuation parameter for noninvasive assessment of steatosis using Fibroscan: validation in chronic hepatitis C. J Viral Hepat. 2012;19:244-53.

11. de Lédinghen V, Vergniol J, Foecher J, Merrouche W, le Bail B. Non-invasive diagnosis of liver steatosis using controlled attenuation parameter (CAP) and transient elastography. Liver Int. 2012;32:911-8.

12. Gallego-durán R, Cerro-Salido P, Gomez-Gonzalez E, Pareja MJ, Ampuero J, Rico MC, et al. Imaging biomarkers for steatohepatitis and fibrosis detection in non-alcoholic fatty liver disease. Scientific Reports. 2016 6:31421.

13. Dhiel AM, Day C. Cause, Pathogenesis, and Treatment of Nonalcoholic Steatohepatitis. The New England Journal of Medicine. 2017;377:2063-72.

14. Abrams GA, Kunde SS, Lazenby AJ, Clements RH. Portal Fibrosis and Hepatic Steatosis in Morbidly Obese Subjects: A Spectrum of Nonalcoholic Fatty Liver Disease. Hepatology. 2004;40:475-83

15. Uslusoy HS, Nak SG, Gülten M. Noninvasive predictors for liver fibrosis in patients with nonalcoholic steatohepatitis. World J Hepatol. 2011;3:219-27.

16. Suzuki K, Yoneda M, Imajo K, Kirikoshi H, Nakajima A, Maeda S, Saito S Transient elastography for monitoring the fibrosis of non-alcoholic fatty liver disease for 4 years. Hepatol Res. 2013;43:979-983.

17. Argo CK, Northup PG, Al-Osaimi AM, Caldwell SH. Systematic review of risk factors for fibrosis progression in non-alcoholic steatohepatitis. J Hepatol. 2009;51:371-9.

18. Wong VW, Vergniol J, Wong GL, Foucher J, Chan HL, Le Bail B, et al. Diagnosis of fibrosis and cirrhosis using liver stiffness measurement in nonalcoholic fatty liver disease. Hepatology. 2010;51:454-62.

19. Singh S, Allen AM, Wang Z, Prokop LJ, Murad MH, Loomba R. Clin Gastroenterol Hepatol. 2015;13:643-54 